\section{Greenhouse Production of Jatropha, a Potential Biofuel Crop}

\author{
Kimberly Moore ${ }^{1,3,6}$, Scott Greenhut ${ }^{1,4}$, and \\ Wagner Vendrame $e^{1,2,5}$
}

\begin{abstract}
AdDitional INDEX wORDs. biofuel, biodiesel, bioenergy, Jatropha curcas
Summary. The objective of this study was to evaluate greenhouse techniques for the production of jatropha ( Jatropha curcas). Jatropha seedlings were transplanted into 1-gal containers filled with bark mix, coir, or peat-based substrate and fertilized with $0,4.1,5.9$, or $8.3 \mathrm{oz} / \mathrm{ft}^{3}$ of a $15 \mathrm{~N}-4.05 \mathrm{P}-9.96 \mathrm{~K}$ controlled-release fertilizer (CRF). Plants were watered every 2,3 , or 4 days for 80 days in the greenhouse. Jatropha plants grown in peat-based substrate had greater stem diameter and shoot dry weight (SDW) than plants grown in bark mix. For each growing substrate, plants fertilized with 8.3 and $5.9 \mathrm{oz} / \mathrm{ft}^{3}$ of CRF had greater SDW than plants fertilized with 4.1 and $0 \mathrm{oz} / \mathrm{ft}^{3}$ of CRF. Similarly, for all three substrates, plants irrigated every 2 or 3 days had greater SDW than plants irrigated every 4 days. Although jatropha has been classified as a low-nutrient and water requiring plant, the results of this study suggest that increased inputs of fertilizer and water produce larger plants. Further research needs to be conducted on the benefit of larger plants from the greenhouse on subsequent oil production in the field.
\end{abstract}

J atropha is a small tree or a large shrub that can reach a height of up to $5 \mathrm{~m}$ and has been identified as a potential source of sustainable biodiesel production because of its high oil content in seeds $(30 \%-40 \%$ by weight) (Basha and Sujatha, 2007; Heller, 1996; King et al., 2009). Biofuels are in demand worldwide as a replacement for fossil fuels. Jatropha-based biofuels have been used since World War II in Madagascar, Cape Verde, and Benin, and some of its fuel parameters have met German and Austrian standards (Foidl et al., 1996). India also has invested in jatropha as a biofuel; the Ministry of Rural Development estimates that some 500,000-600,000 ha of jatropha has been planted, and some

We thank Luci Fisher and Cheryl Zegelbone for their technical assistance.

Mention of any trade names does not imply endorsement of the products named or criticism of similar ones not named. The cost of publishing this paper was defrayed in part by payment of page charges. Under postal regulations, this paper must therefore be marked advertisement solely to indicate this fact.

${ }^{1}$ Environmental Horticulture Department, Fort Lauderdale Research and Education Center, IFAS, University of Florida, 3205 College Avenue, Fort Lauderdale, FL 33314

${ }^{2}$ Environmental Horticulture Department, Tropical Research and Education Center, IFAS, University of Florida, 18905 SW 280 St, Homestead, FL 33031

${ }^{3}$ Associate Professor

${ }^{4}$ Graduate student

${ }^{5}$ Associate Professor

${ }^{6}$ Corresponding author. E-mail: klock@ufl.edu. vehicle test runs have shown the performance of the oil to compare favorably with that of the fuels from other feedstocks (Fairless, 2007). China and Burma have plans to scale up production of this potential biofuel crop. Fairless (2007) reported that, in Summer 2005, they ran a successful road test using $100 \%$ jatropha biodiesel "without any significant engine modifications" (Fairless, 2007).

Jatropha has been reported to be native to Central America and Mexico where it occurs naturally in the forests of coastal regions (King et al., 2009). It is widely cultivated in the tropics as a living fence in fields and settlements because it is not browsed by cattle or livestock. Reports claim that jatropha is a drought-resistant plant that has the potential for cultivation in semiarid marginal soils, without competing with food crops (Heller, 1996). Recently, jatropha has received increased attention worldwide and has attracted interest from growers seeking alternative crops. However, research on jatropha in the United States is limited, and a thorough assessment is needed to understand its biology, cultural practices, and potential yields. Although jatropha survives on marginal soils, copious oil yields may not be obtained under those conditions. Furthermore, jatropha's water use has been recently debated. Gerbens-Leenes et al. (2009) list jatropha as the bioenergy crop with the greatest water footprint per electricity output $\left(396 \mathrm{~m}^{3} \cdot \mathrm{GJ}^{-1}\right.$ electricity) based on high yields under optimal conditions, whereas Jongschaap et al. (2009) suggested that this value did not take into account specific characteristics of soils, and background information did not supply essential information to correct reference evaporation. They estimated that the water footprint of jatropha is closer to 128 $\mathrm{m}^{3} \cdot \mathrm{GJ}^{-1}$ electricity. Little research has been conducted on the feasibility, methods, and costs of greenhouse and field production of jatropha in the United States.

Jatropha is easy to propagate, hardy, and grows relatively fast (Openshaw, 2000). However, a major constraint for extended use of jatropha appears to be the knowledge of potential yield as it relates to production and cultivation practices (Jongschaap et al., 2007). The proposed research will help to close existing technology gaps and generate data to clarify jatropha cultivation and production practices. Our objective was to examine greenhouse production by investigating

\begin{tabular}{llll}
\hline $\begin{array}{l}\text { Units } \\
\begin{array}{l}\text { To convert U.S. to SI, } \\
\text { multiply by }\end{array}\end{array}$ & U.S. unit & SI unit & $\begin{array}{l}\text { To convert SI to U.S., } \\
\text { multiply by }\end{array}$ \\
\hline 0.4047 & $\mathrm{acre}(\mathrm{s})$ & $\mathrm{ha}$ & $2.471 \mathrm{l}$ \\
29.5735 & $\mathrm{fl} \mathrm{oz}$ & $\mathrm{mL}$ & 0.0338 \\
0.3048 & $\mathrm{ft}$ & $\mathrm{m}$ & 3.2808 \\
0.0283 & $\mathrm{ft}^{3}$ & $\mathrm{~m}^{3}$ & 35.3147 \\
3.7854 & $\mathrm{gal}$ & $\mathrm{L}$ & 0.2642 \\
2.54 & inch $(\mathrm{es})$ & $\mathrm{cm}$ & 0.3937 \\
1.1209 & $\mathrm{lb} / \mathrm{acre}$ & $\mathrm{kg} \cdot \mathrm{ha}^{-1}$ & 0.8922 \\
1 & $\mathrm{meq} / 100 \mathrm{~g}$ & $\mathrm{cmol} \cdot \mathrm{kg}^{-1}$ & 1 \\
1 & $\mathrm{mmhh} / \mathrm{cm}$ & $\mathrm{dS} \cdot \mathrm{m}^{-1}$ & 1 \\
0.2778 & $\mathrm{MWh}$ & $\mathrm{GJ}$ & 3.6000 \\
28.3495 & $\mathrm{oz}$ & $\mathrm{g}$ & 0.0353 \\
1.0012 & $\mathrm{Oz} / \mathrm{ft}^{3}$ & $\mathrm{~kg} \cdot \mathrm{m}^{-3}$ & 0.9988 \\
1 & $\mathrm{ppm}$ & $\mathrm{mg} \cdot \mathrm{L}^{-1}$ & 1 \\
10.7639 & $\mathrm{~W} / \mathrm{ft}^{2}$ & $\mathrm{~W} \cdot \mathrm{m}^{-2}$ & 0.0929 \\
$\left({ }^{\circ} \mathrm{F}-32\right) \div 1.8$ & ${ }^{\circ} \mathrm{F}$ & ${ }^{\circ} \mathrm{C}$ & $\left(1.8 \times{ }^{\circ} \mathrm{C}\right)+32$ \\
& & &
\end{tabular}

Horflechnology · April $201121(2)$ 
the use of different growing substrates, fertilizers, and irrigation frequencies to produce jatropha.

\section{Materials and methods}

Seeds of jatropha from India were germinated in $4.5 \times 4.5 \times$ $4.5-\mathrm{cm}$ cells filled with Jiffy Mix (Jiffy Products of America, Lorain, $\mathrm{OH}$ ) under mist. The mist system ran for 20 s every 4 min from 6:00 AM to 7:00 PM daily. The seeds had germinated after $7 \mathrm{~d}$. About $21 \mathrm{~d}$ after sowing, uniform seedlings with first true leaves were transplanted into 1-gal containers filled with 1) bark mix $[50 \%$ pine bark, $40 \%$ Florida sedge peat, $10 \%$ sand (by volume); Atlas Peat and Soil, Boyton Beach, FL], 2) coir (100\% coconut coir; densu Ventures, Hamilton, $\mathrm{ON}$, Canada), or 3 ) peat substrate [greenhouse substrate, $80 \%-85 \% \mathrm{Ca}-$ nadian sphagnum peatmoss (by volume), perlite, and vermiculite (Promix BX; Premier Horticulture, Red Hill, PA)]. Before transplanting, a $15 \mathrm{~N}-$ 4.05P-9.96K controlled-release fertilizer (Osmocote Plus, 8-9 month Southern release; Scotts-Sierra Horticultural Products, Marysville, $\mathrm{OH}$ ) was incorporated into each substrate at $0,4.1,5.9$, or $8.3 \mathrm{oz} / \mathrm{ft}^{3}$. Three substrate samples were collected at this time and sent to A\&L Southern Laboratories (Deerfield Beach, FL) for analysis of moisture content (percent available moisture by weight after saturation and drainage; samples oven dried at $103{ }^{\circ} \mathrm{C}$ ), cation exchange capacity (CEC), $\mathrm{pH}$, and electrical conductivity (EC).

Plants were watered by hand every 2, 3, or $4 \mathrm{~d}$ with $650 \mathrm{~mL}$ of water per pot. The irrigation frequencies were chosen to emulate current industry practices that apply water using automated systems that deliver water at equal time intervals. Within each irrigation frequency, all plants received the same amount of water regardless of the type of growing substrate. The irrigation water used throughout the experiment had 0.36 $\mathrm{dS} \cdot \mathrm{m}^{-1} \mathrm{EC}, 94 \mathrm{mg} \cdot \mathrm{L}^{-1}$ calcium carbonate total alkalinity, $0.6 \mathrm{mg} \cdot \mathrm{L}^{-1}$ nitrate nitrogen $\left(\mathrm{NO}_{3}-\mathrm{N}\right), 28 \mathrm{mg} \cdot \mathrm{L}^{-1}$ calcium, $6 \mathrm{mg} \cdot \mathrm{L}^{-1}$ magnesium, and $22 \mathrm{mg} \cdot \mathrm{L}^{-1}$ sodium.

Ten replicates of each treatment combination were placed in a greenhouse, with mean ambient air temperatures of $30 / 21{ }^{\circ} \mathrm{C}$ day/night, an average relative humidity of $75 \%$, and average light levels in the greenhouse of $246.8 \mathrm{~W} \cdot \mathrm{m}^{-2}$. The first experiment was initiated in July 2009 and conducted for $80 \mathrm{~d}$ at which point roots had started to circle in the containers and plants were large enough to be transplanted to the field. Average day length

Table 1. Pooled factorial analysis of variance of final shoot dry weight (SDW), root dry weight (RDW), and stem diameter of jatropha plants grown in bark substrate, coir, or peat substrate and fertilized with $0,4.1,5.9$, or $8.3 \mathrm{oz} / \mathrm{ft}^{3}$ of a $15 \mathrm{~N}-4.05 \mathrm{P}-9.96 \mathrm{~K}$ controlled-release fertilizer incorporated into the substrate and irrigated every 2,3 , or $4 \mathrm{~d}$. The factorial is 3 substrate $\times 4$ fertilization rates $\times$ 3 irrigation frequencies; $1 \mathrm{oz} / \mathrm{ft}^{3}=1.0012 \mathrm{~kg} \cdot \mathrm{m}^{-3}$.

\begin{tabular}{lccc}
\hline & \multicolumn{3}{c}{ Probability } \\
\cline { 2 - 4 } Source of variation & SDW & RDW & Stem diameter \\
\hline Substrate & 0.0001 & 0.0001 & 0.0001 \\
Fertilization rate & 0.0001 & 0.0183 & 0.1882 \\
Irrigation rate & 0.0001 & 0.0001 & 0.0001 \\
Substrate $\times$ fertilizer & 0.0327 & 0.0011 & 0.0060 \\
Substrate $\times$ irrigation & 0.0052 & 0.0211 & 0.0172 \\
Fertilizer $\times$ irrigation & 0.3044 & 0.2986 & 0.7407 \\
Substrate $\times$ fertilizer $\times$ irrigation & 0.7432 & 0.1000 & 0.8236 \\
\hline
\end{tabular}
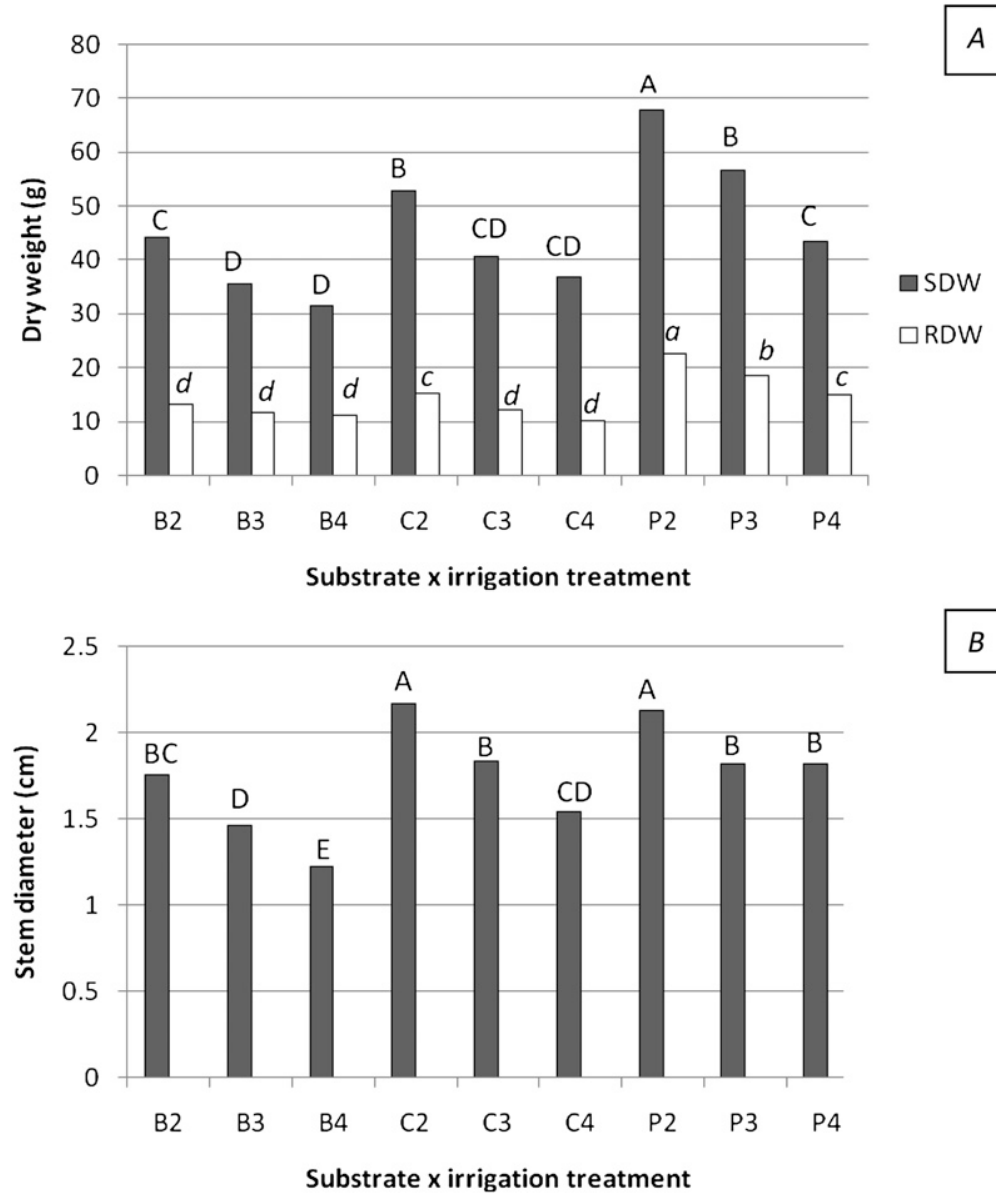

Fig. 1. (A) Shoot dry weight (SDW) and root dry weight (RDW), and (B) stem diameter of jatropha plants growing in bark mix $(B)$, coir $(C)$, or peat substrate $(P)$ and irrigated every 2,3 , or $4 \mathrm{~d}$ for $80 \mathrm{~d}$ in the greenhouse. Average mean values were combined across four fertilization rates. Means followed by different letter are significantly different via Tukey's honestly significant difference test at $\alpha=0.05$. Lowercase letters correlate with RDW while uppercase letters are correlated with SDW or stem caliper, respectively. Standard errors for SDW, RDW, and stem diameter are $1.8,0.4$, and 0.07 , respectively $(N=40) ; 1 \mathrm{~g}=0.0353 \mathrm{oz}, 1 \mathrm{~cm}=0.3937$ inch. 
from July to September ranged from $13 \mathrm{~h} 30 \mathrm{~min}$ to $11 \mathrm{~h} 55 \mathrm{~min}$. The entire experiment was repeated in Feb. 2010 for the same duration in the same greenhouse. Average day length from February to April ranged from 11 h 36 $\mathrm{min}$ to $13 \mathrm{~h} 7 \mathrm{~min}$. Temperature and relative humidity in the greenhouse were similar to the those in July, but average light levels in the greenhouse were $\approx 207.2 \mathrm{~W} \cdot \mathrm{m}^{-2}$.

At termination, stem diameter was recorded. Stem diameter was measured $15 \mathrm{~cm}$ above the substrate surface. Shoots were cut at the substrate surface, dried at $93{ }^{\circ} \mathrm{C}$ for $48 \mathrm{~h}$ and weighed. Roots were removed from containers by gently shaking substrate from the root ball and then rinsing roots under water until no substrate remained. Roots were dried according to the method described for shoots and then weighed.

Data analysis. The experiment was designed as a randomized threeway factorial with three substrates, four fertilization rates, and three irrigation frequencies. Each repetition of the experiment was analyzed separately. Data were also statistically compared between the two repetitions, and no differences in results were observed $(P>F=0.4567)$. Because the effects of substrate, fertilization, and irrigation frequency were similar between the two repetitions, the results were pooled for further analysis. Differences in SDW, RDW, stem diameter, and initial substrate moisture, $\mathrm{pH}$, and $\mathrm{EC}$ were analyzed using the PROC MIXED procedure in SAS (version 9.1; SAS Institute, Cary, NC). All pairwise comparisons were completed using Tukey's honestly significant difference test with a significant level of $\alpha=0.05$.

\section{Results and discussion}

We did observe significant growth responses to substrate, irrigation frequency, and fertilization rate and significant substrate-by-irrigation frequency and substrate-by-fertilization rate interactions (Table 1). There was no significant irrigation-by-fertilization rate interactions, and there was no substrate by irrigation frequency-by-fertilizer rate interactions for any of the growth parameters measured (Table 1 ).

For all three substrates, plants irrigated every $2 \mathrm{~d}$ had greater SDW and stem diameter than plants irrigated every $4 \mathrm{~d}$ (Fig. 1). A similar trend was observed for RDW of plants grown in peat substrate and coir, but there was no difference in RDW due to irrigation frequency for plants grown in bark mix (Fig. 1). Although jatropha is well adapted to arid and semiarid conditions and can survive prolonged periods without rain, the plant sheds its leaves as a response to drought and does not produce well under these conditions (Kumar and Sharma, 2008; Ouwens et al., 2007). Jatropha tends to grow well in welldrained soils, with good aeration and an optimal rainfall of 1,000 to 15,000 $\mathrm{mm} \cdot \mathrm{ha}^{-1}$ per year (Kumar and Sharma, 2008; Ouwens et al., 2007). We suspect that greater moisture content of peat substrate along with more frequent irrigation resulted in greater growth in these substrates compared with bark mix (Table 2). KlockMoore and Broschat (2001) also reported that SDW of pentas (Pentas lanceolat), crossandra (Crossandra infundibuliformis), and philodendron (Philodendron 'Hope') was greater in subirrigated pots filled with peat substrate than with bark mix.
The initial moisture content, container capacity, and total pore space was also greater in peat substrates than in bark mix or biosolid substrate (Klock-Moore and Broschat, 2001).

Similarly, growth in coir irrigated every $2 \mathrm{~d}$ was greater than growth in the bark mix irrigated every $2 \mathrm{~d}$ but less than the peat substrate irrigated every $2 \mathrm{~d}$ (Fig. 1). Ouwens et al. (2007) report that under some soil conditions, such as waterlogged areas, jatropha will fail to grow. It is possible that irrigating every $2 \mathrm{~d}$ with coir trapped too much moisture while irrigating every $2 \mathrm{~d}$ with the bark substrate did not trap enough moisture for jatropha.

Peat substrate and coir also had greater cation exchange capacity than bark mix, but there was no difference in substrate $\mathrm{pH}$ (Table 2). Jatropha plants grown in peat substrate had greater SDW s, RDWs, and stem diameters than plants grown in coir or bark mix (Figs. 1 and 2). The peat substrate used did contain a nutrient pre-charge of $220 \mathrm{mg} \cdot \mathrm{L}^{-1} \mathrm{NO}_{3}-\mathrm{N}$, $45 \mathrm{mg} \cdot \mathrm{L}^{-1}$ phosphate, and $120 \mathrm{mg} \cdot \mathrm{L}^{-1}$

Table 2. Initial substrate moisture holding capacity, cation exchange capacity (CEC), $\mathrm{pH}$, and electrical conductivity (EC) of bark mix, coir, and peat substrate with $15 \mathrm{~N}-4.05 \mathrm{P}-9.96 \mathrm{~K}$ controlled-release fertilizer incorporated into the substrate for the growth of jatropha plants. Analysis was performed by A\&L Southern Agricultural Laboratories (Deerfield Beach, FL).

\begin{tabular}{lccccc}
\hline Substrate & $\begin{array}{c}\text { Fertilization } \\
\left(\mathbf{o z} / \mathrm{ft}^{3}\right)^{\mathbf{z}}\end{array}$ & $\begin{array}{c}\text { Moisture } \\
\text { content }(\%)^{\mathbf{y x}}\end{array}$ & $\begin{array}{c}\text { CEC } \\
(\mathbf{m e q} / \mathbf{1 0 0} \mathbf{g})^{\mathbf{z x}}\end{array}$ & $\mathbf{p H}^{\mathbf{x}}$ & $\begin{array}{c}\text { EC } \\
(\mathbf{m m h o} / \mathbf{c m})^{\mathbf{z x}}\end{array}$ \\
\hline Bark mix & 0 & $32 \mathrm{c}^{\mathrm{x}}$ & $35 \mathrm{c}$ & $6.6 \mathrm{a}$ & $0.10 \mathrm{e}$ \\
& 4.1 & $31 \mathrm{c}$ & $25 \mathrm{c}$ & $6.0 \mathrm{a}$ & $0.25 \mathrm{~d}$ \\
& 5.9 & $31 \mathrm{c}$ & $30 \mathrm{c}$ & $5.9 \mathrm{a}$ & $1.68 \mathrm{~b}$ \\
& 8.3 & $33 \mathrm{c}$ & $33 \mathrm{c}$ & $5.0 \mathrm{a}$ & $1.83 \mathrm{ab}$ \\
Coir & & & & & \\
& 4.1 & $54 \mathrm{a}$ & $67 \mathrm{~b}$ & $6.5 \mathrm{a}$ & $0.12 \mathrm{e}$ \\
& 5.9 & $57 \mathrm{a}$ & $77 \mathrm{~b}$ & $6.5 \mathrm{a}$ & $0.40 \mathrm{~d}$ \\
& 8.3 & $55 \mathrm{a}$ & $75 \mathrm{~b}$ & $5.5 \mathrm{a}$ & $2.30 \mathrm{a}$ \\
Peat substrate & 0 & $43 \mathrm{~b}$ & $119 \mathrm{a}$ & $6.8 \mathrm{a}$ & $2.50 \mathrm{a}$ \\
& 4.1 & $49 \mathrm{~b}$ & $113 \mathrm{a}$ & $5.7 \mathrm{a}$ & $0.21 \mathrm{~d}$ \\
& 5.9 & $43 \mathrm{~b}$ & $115 \mathrm{a}$ & $5.3 \mathrm{a}$ & $1.98 \mathrm{ab}$ \\
& 8.3 & $49 \mathrm{~b}$ & $116 \mathrm{a}$ & $5.8 \mathrm{a}$ & $2.46 \mathrm{a}$
\end{tabular}

Significance $^{\mathrm{w}}$

\begin{tabular}{lcccl} 
Substrate & 0.0001 & 0.0001 & NS & 0.05 \\
Fertilizer & NS & NS & NS & 0.0001 \\
Substrate $\times$ fertilizer & NS & NS & NS & 0.001 \\
SE & 1.48 & 2.34 & 0.17 & 0.11 \\
\hline
\end{tabular}

${ }^{2} 1 \mathrm{oz} / \mathrm{ft}^{3}=1.0012 \mathrm{~kg} \cdot \mathrm{m}^{-3}, 1 \mathrm{meq} / 100 \mathrm{~g}=1 \mathrm{cmol} \cdot \mathrm{kg}^{-1}, 1 \mathrm{mmho} / \mathrm{cm}=1 \mathrm{dS} \cdot \mathrm{m}^{-1}$

"Percent available moisture by weight after saturation and drainage; samples oven dried at $103{ }^{\circ} \mathrm{C}\left(217.4{ }^{\circ} \mathrm{F}\right)$.

${ }^{\mathrm{x}}$ Means within each column followed by different letter are significantly different via Tukey's honestly significant difference (HSD) test at $\alpha=0.05(N=3)$.

"NS indicates that the response was not significant via Tukey's HSD test at $\alpha=0.05$; the remaining numbers represent probability of a greater $P$ value. 


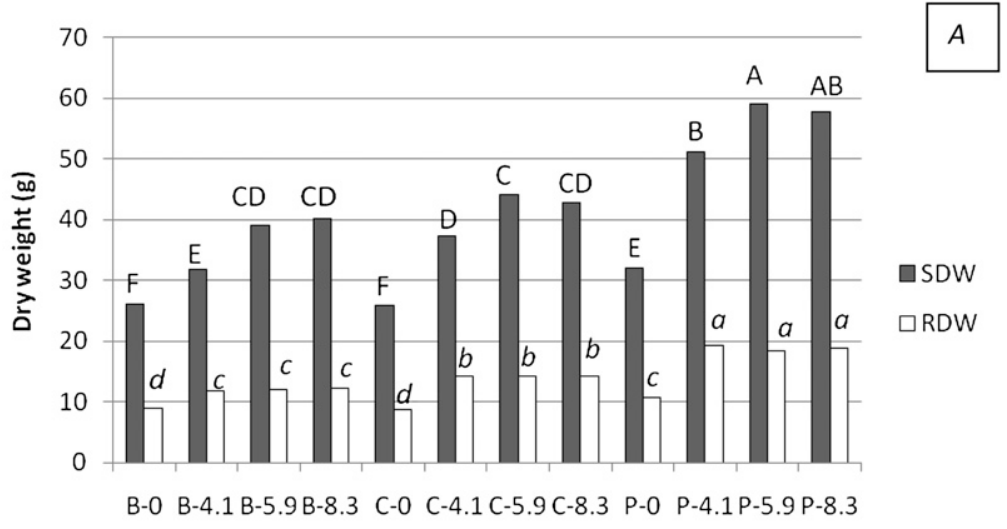

Substrate $x$ fertilizer treatment

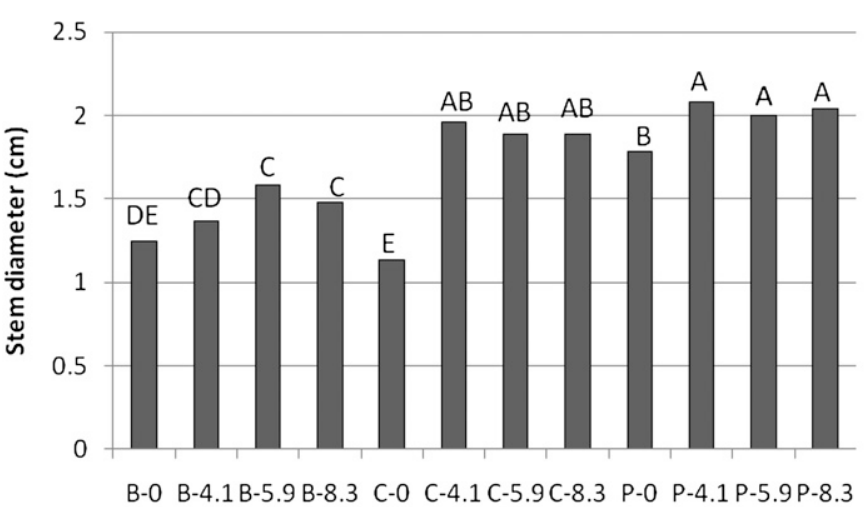

Substrate $\mathrm{x}$ fertilizer treatment
$B$

Fig. 2. (A) Shoot dry weight (SDW) and root dry weight (RDW), and (B) stem diameter of jatropha plants growing in bark mix $(B)$, coir $(C)$, or peat substrate $(P)$ and fertilized with $0,4.1,5.9$, or $8.3 \mathrm{oz} / \mathrm{ft}^{3}\left(1 \mathrm{oz} / \mathrm{ft}^{3}=1.0012 \mathrm{~kg} \cdot \mathrm{m}^{-3}\right) 15 \mathrm{~N}-$ 4.05P-9.96K controlled-release fertilizer incorporated into the substrates before planting. Plants were grown in a greenhouse for $80 \mathrm{~d}$. Average mean values were combined across three irrigation frequencies. Means followed by different letter are significantly different via Tukey's honestly significant difference test at $\alpha=0.05$. Lowercase letters correlate with RDW and uppercase letters correlatewith SDW or stem caliper, respectively. Standard errors for SDW, RDW, and stem diameter are $1.9,0.4$, and 0.07 , respectively $(N=30) ; 1 \mathrm{~g}=0.0353 \mathrm{oz}, 1 \mathrm{~cm}=0.3937$ inch.

potassium. However, as fertilizer application rate increased in all three substrates, substrate EC increased (Table 2). The EC of the peat substrate and coir fertilized at $8.3 \mathrm{oz} / \mathrm{ft}^{3}$ was similar (Table 2).

For all three substrates, average values for SDW, RDW, and diameter were greater for plants fertilized with 8.3 and $5.9 \mathrm{oz} / \mathrm{ft}^{3}$ of fertilizer than with $4.1 \mathrm{oz}$ or $0 \mathrm{oz} / \mathrm{ft}^{3}$ of fertilizer (Fig. 2). The largest plants were produced in the peat substrate with 5.9 or $8.3 \mathrm{oz} / \mathrm{ft}^{3}$ (Fig. 2). Shoot dry weight at these rates for plants grown in coir and bark substrates was similar but less than that in the peat substrate (Fig. 2). Again, it is possible that the pre-plant nutrient charge assisted in increased growth in the peat substrate compared with the growth in other two substrates. However, we suspect that increased CEC and moderate moisture content also contributed to improved growth in the peat substrate.

Root dry weight and stem diameter for all substrates were less in containers with $0 \mathrm{oz}$ of fertilizer than those in other treatments (Fig. 2). There was no difference in RDW or stem diameter among plants fertilized with $4.1,5.9$, or $8.3 \mathrm{oz} / \mathrm{ft}^{3}$ of fertilizer (Fig. 2). Ouwens et al. (2007) reported that jatropha responds to fertilization applications as a chemical fertilizer or organic matter addition in poor soil conditions. Jongschaap et al. (2007) reported increased plant height, leaf area, total aboveground dry matter, seed yield, and oil yield with $\mathrm{N}$ applications of $45 \mathrm{~kg} \cdot \mathrm{ha}^{-1}$ on marginal lands in India compared with $0 \mathrm{~kg} \cdot \mathrm{ha}^{-1}$ of $\mathrm{N}$ application.

Jatropha yields can range from extremely low to high depending on water availability, nutrient availability, and other environmental conditions (Ouwens et al., 2007). Although jatropha has been classified as a droughtresistant plant capable of growing on marginal soils, the results of these experiments suggest that jatropha growth in the greenhouse was increased when irrigation and fertilization were increased. Based on the results presented, we would recommend growing jatropha in containers filled with the peat substrate, fertilizing plants with $5.9 \mathrm{oz} / \mathrm{ft}^{3}$ of CRF, and irrigating plants every $2 \mathrm{~d}$. However, future research needs to be conducted on how management in the greenhouse relates to seed and oil yields in the field.

\section{Literature cited}

Basha, S.D. and M. Sujatha. 2007. Inter and intra-population variability of Jatropha curcas L. characterized by RAPD and ISSR markers and development of population-specific SCAR markers. Euphytica 156:375-386.

Fairless, D. 2007. Renewable energy: Energy-go-round. Nature 447:10461048.

Foidl, N., G. Foidl, M. Sanchez, M. Mittelbach, and S. Hackel. 1996. Jatropha curcas L. as source for the production of biofuel in Nicaragua. Bioresour. Technol. 58:77-82.

Gerbens-Leenes, W., A.J. Hoekstra, and T.H. van der Meer. 2009. The water footprint of bioenergy. Proc. Natl. Acad. Sci. USA 106:10219-10223.

Heller, J. 1996. Physic nut Jatropha curcas L. 30 Nov. 2010 . <www. bioversityinternational.org/nc/.../physic_ nut_brijatropha_curcasi_l.html>.

Jongschaap, R.E.E., R.A.R. Blesgraaf, T.A. Bogaard, E.N. van Loo, and H.H.G. Savenije. 2009. The water footprint of bioenergy of Jatropha curcas L. Proc. Natl. Acad. Sci. USA 106:92.

Jongschaap, R.E.E., W.J. Corre, P.S. Bindraban, and W.A. Brandenburg. 2007. Claims and facts on Jatropha curcas L., global Jatropha curcas evaluation, breeding and propagation program. $10 \mathrm{Feb}$. 2011. <http://edepot.wur.nl/41683/>.

King, A.J., W. He, I.A. Graham, J.A. Cuevas, M. Freudenberger, and D. Ramiaramanana. 
2009. Potential of Jatropha curcas as a source of renewable oil and animal feed. J. Expt. Bot. 60:2897-2905.

Klock-Moore, K.A. and T.K. Broschat. 2001. Effect of four growing substrates on growth of ornamental plants in two irrigation systems. HortTechnology 11: $456-460$
Kumar, A. and S. Sharma. 2008. An evaluation of multipurpose oil seed crop for industrial uses (Jatropha curcas L.): A review. Ind. Crops Prod. 28:1-10.

Openshaw, K. 2000. A review of Jatropha curcas: An oil plant of unfilled promise. Biomass Energy 19:1-15.
Ouwens, K.D., G. Francis, Y.J. Franken, W. Rijssenbeek, A. Riedacjer, N. Foidl, R. Jongschapp, and P. Bindraban. 2007. Position paper on Jatropha curcas state of the art, small and large scale project development. 10 Feb. 2011. <http:// www.fact-foundation.com/media_en/ Position_Paper_on_Jatropha_Curcas/>. 